Research article

\title{
Citrus varieties of Kokrajhar District, BTAD, Assam: Its propagation and cultivation prospect
}

\author{
Mohesh Gogoi ${ }^{1 *}$ and Miniswrang Basumatary ${ }^{2}$ \\ ${ }^{1}$ Department of Botany, Biotech Hub, Science College, Kokrajhar, BTAD, Assam \\ ${ }^{2}$ Biotech Hub, Science College, Kokrajhar, BTAD, Assam
}

*Corresponding Author: mohesh.gogoi@ rediffmail.com

[Accepted: 08 January 2017]

\begin{abstract}
Citrus spp. grows in different localities of Kokrajhar district (BTAD), Assam and this place is a natural home to many varieties of the said fruit. Even though a favorable agro-climatic condition for citrus growth prevails in the region the production is not sufficient. Using inappropriate rootstock as well as the seedling is cultivation bottleneck that has been learned from the orchardists. The studies revealed that right type of seedling produced by using standardized nursery technique ensure healthy growth and optimum production. This paper deals with distribution of the different citrus varieties that grow in wild, semi-wild and cultivated forms in Kokrajhar district and usefulness of different vegetative propagation technique along with seed germination.
\end{abstract}

Keywords: Citrus - Propagation - Cutting - Layering - Orchard.

[Cite as: Gogoi M \& Basumatary M (2017) Citrus varieties of Kokrajhar District, BTAD, Assam: Its propagation and cultivation prospect. Tropical Plant Research 4(1): 7-12]

\section{INTRODUCTION}

Citrus (Citrus L.) is one of the world's most important fruit crops, distributed in the tropical and subtropical regions of the world (Randhwa \& Srivastava 1986). They are grouped under the family Rutaceae and subfamily Aurantioideae (Singh 1981, Gogoi et al. 2003). Swingle (1943) have divided Citrus into two subgenera, Citrus (formerly Eucitrus) and Papeda. In this regard, Bhattacharya \& Dutta (1956) have postulated that the species belonging to the subgenus Citrus are economically more important than those of the subgenus Papeda. Citrus is the third most important fruit crop in India (Ghosh 1999). NE region of the country alone produces an annual production of 7,91,000.36 metric tons (Govt. of Assam report 2012-13) which are considered to be a major citrus growing zone (Singh 1999). As per Govt. of Assam report 2012-13 the state alone could ably produce 3, 23,000.39 metric tons which account for $40 \%$ of the total annual production of Citrus in the region. Except for few upper Assam districts, the border areas of Nagaland and Arunachal Pradesh and a large part of BTAD provide ample scope for citrus cultivation. BTAD comprises four districts viz. Kokrajhar, Chirang, Baksa and Udalguri with a total area of $8,970 \mathrm{~km}^{2}$ out of which $2,562 \mathrm{~km}^{2}$ is delineated as forest area (28.6\%), while nonforest area is 6, $408 \mathrm{~km}^{2}$ (Gogoi \& Bhansali 2015). Among the four districts of BTAD, Kokrajhar district provides a suitable agro-climatic condition for large-scale citrus cultivation which is bounded by Bhutan in North, Dhubri district in South, Bongaigaon and Chirang district in East and West Bengal in West. As per BTC report (Dept. of Forest), the total geographical area of Kokrajhar district is 3,98,635 ha out of which total 151680 ha is cultivable land, and the gross crop and net crop area is 168561 ha and 108916 ha respectively. Santana (Citrus reticulata) varieties are extensively cultivated all over the district where the total production was 173 metric ton in 2010-11 and 365 metric ton in 2011-12. On the other hand lemon (C. limon) and lime $(C$. aurantifolia) varieties has high market demand that encourages the orchardists to grow citrus in their backyard and kitchen garden as well. It has been reported by district Agriculture \& Horticulture office, Kokrajhar that the total citrus production was 238 metric ton in 2010-11 and 365 metric ton in 2011-12 but the production was reported to be too less to fulfill the market demand. To understand the distribution pattern, availability, and problems related to citrus cultivation, an extensive study was carried out with the financial support of UGC in 
the form of the minor research project. Various propagation methods have been employed for improvement of the quality of seedling by developing nursery.

\section{MATERIALS AND METHODS}

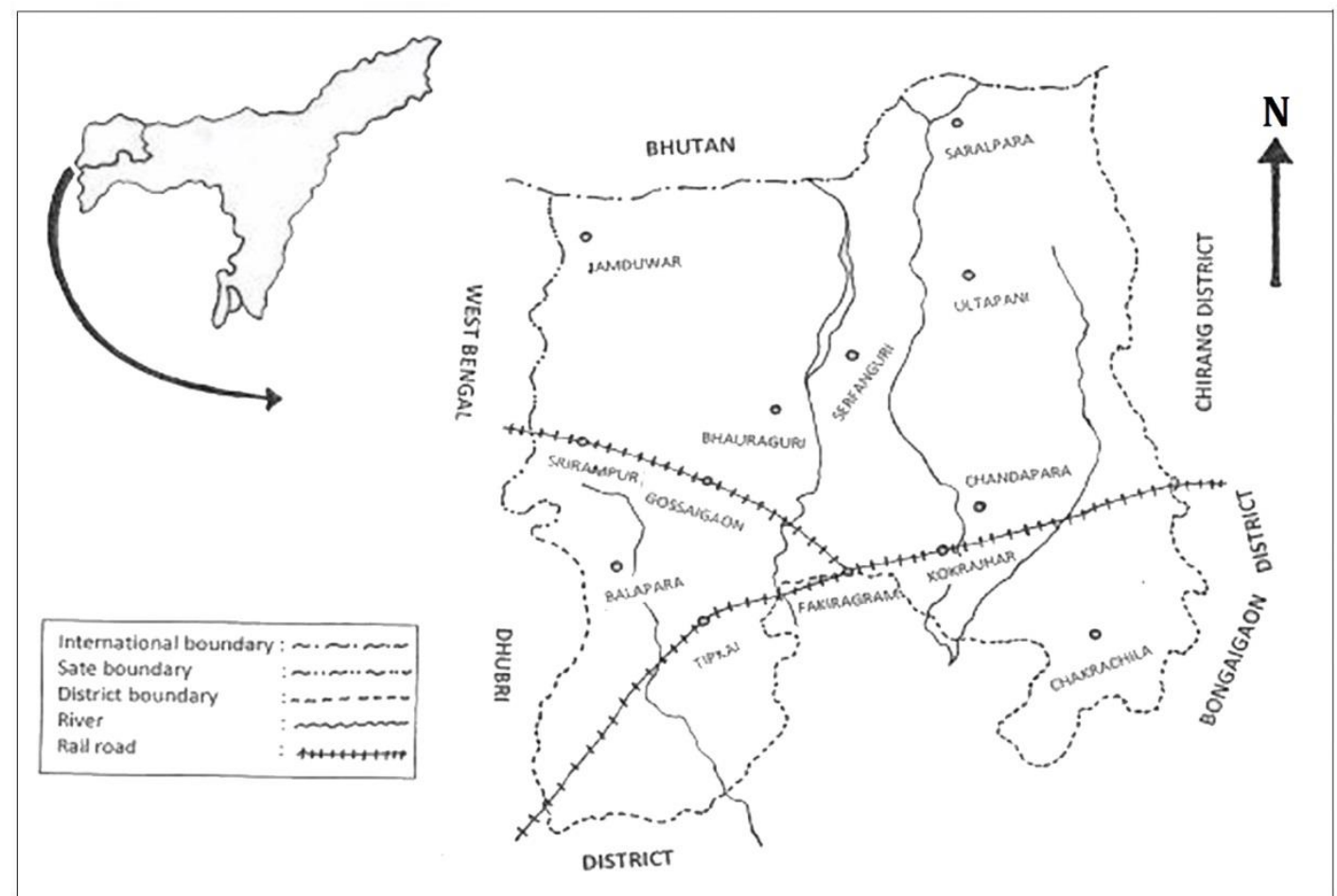

Figure 1. Map of Kokrajhar district showing the localities from where the Citrus varieties have been collected.

A thorough survey was conducted in between 2013-14 in different areas of Kokrajhar district (Fig. 1) for Citrus species in two different seasons covering its complete phenophase (Gogoi 2014). Detailed observation of plant species was made scoring the data on habitat, morphology of the whole plant, phenology, ecology and associated plants. All the taxonomic details and other information have been recorded in a 'descriptive blank' as per the model of H. J. Webber (Webber 1943) and UPOV TF/83/3. The geographical, environmental and soil parameters of the places were noted and later a map was drawn showing the citrus growing localities of the district. A general identification of the collected species was done with the help of standard taxonomic literature. The careful collection was made for herbarium specimen following the methodology of Lawrence (1951) and Jain \& Rao (1977). Thereafter, comparison was made with authentic specimens deposited at BSI herbarium, Shillong and BSI herbarium, Calcutta.

For sapling preparation and propagation fresh cuttings about 5-10 cm lengths (Rajput \& Haribabu 1985) of Citrus limon Brum f., C. medica L. and C. aurantifolia Swin. by applying growth promoting hormone were later planted during March-May, 2013. One year old branches of above mentioned three Citrus species were planted in the nursery bed. The tubs were regularly irrigated with an adequate amount of water. The data were taken at fortnightly interval up to 90 days. Simultaneously mature fruits of each plant were collected for histological observation.

Further to examine the quality of propagules a series of nursery experiment was conducted within the shade house for their performance by using the method of Dutta (1964), Mukharjee \& Majumder (1983), Williamson \& Jackson (1994), Kalita et al. (2002) and Singh (2012). The rooting behavior was also studied by means of multiple nodes cutting and layering method followed by Chaudhury \& Chakwawar (1980), Singh et al. (2004).

\section{RESULTS AND DISCUSSION}

After an extensive survey and detailed morphological observation, a total of 8 species and 5 varieties including both wild and cultivated forms have been identified (Table 1). Three varieties of Citrus limon (Assam lebu/China lebu, Elachi lebu/Cardamom lemon, Pati lebu/Jora nemu), two varieties of Citrus aurantifolia (Abhayapuri lime/oval-fruited and Karimganj lime/round-fruited) and each variety of Citrus jambhiri, Citrus reticulata, Citrus nobilis, Citrus grandis, Citrus medica, Citrus sinensis were recorded. 
Table 1. Identified Citrus species of Kokrajhar district.

\begin{tabular}{lll}
\hline Sl. No. & Species identified & Varieties identified \\
\hline 1 & Citrus limon Brum f. & $\begin{array}{l}\text { Assam lebu/China lebu, Elachi lebu/Cardamom lemon, Pati } \\
\text { lebu/Jora nemu }\end{array}$ \\
2 & Citrus aurantifolia (Christm.) Swin. & $\begin{array}{l}\text { Abhayapuri lime (Oval fruited) and Karimganj lime } \\
\text { (Round-fruited) }\end{array}$ \\
3 & Citrus jambhiri Lush. & A round fruited variety locally called gulnemu \\
4 & Citrus reticulata Blanco & A common mandarin variety \\
5 & Citrus nobilis Lour & Semi-domesticated variety locally called jeneru tenga \\
6 & Citrus grandis L. Osbeek & Juice vesicle pink coloured variety locally called jambura \\
7 & Citrus medica L. & Wild growing variety with mamilate fruit apex \\
8 & Citrus sinensis L. Osbeek & A hybrid variety locally called mithamuri
\end{tabular}
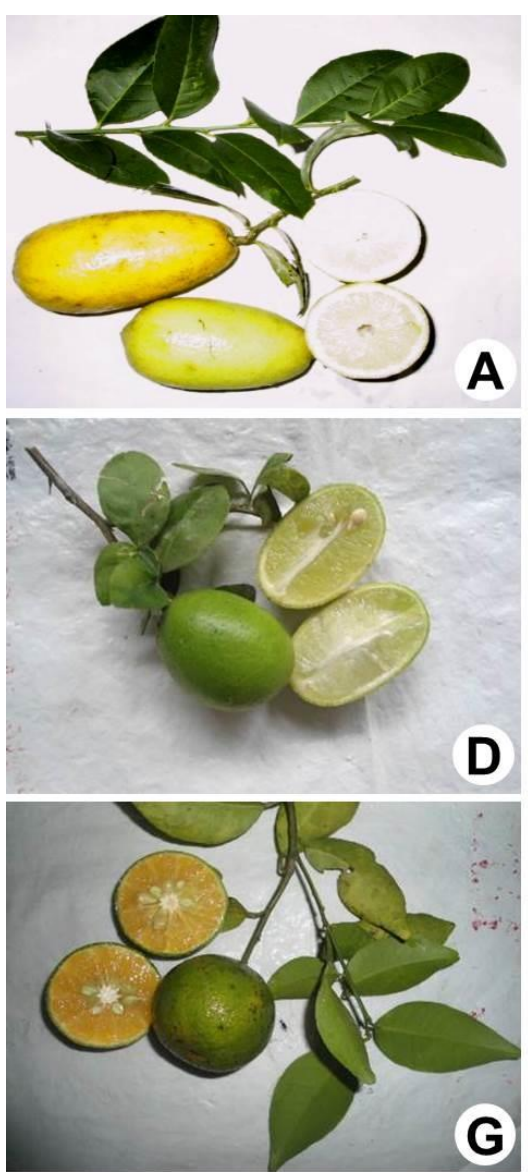

G

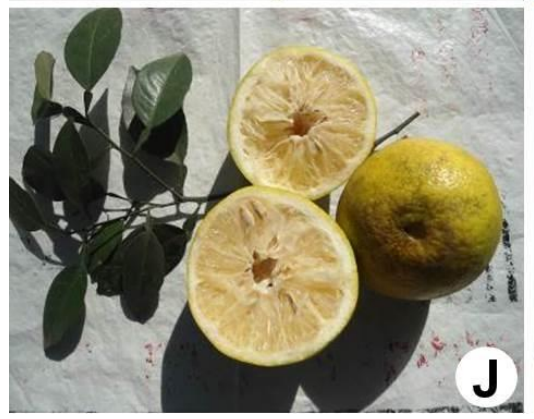

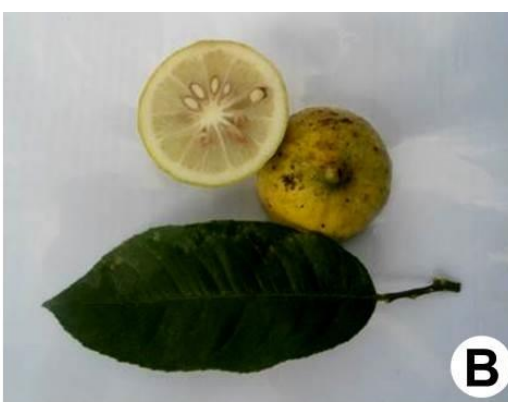

B

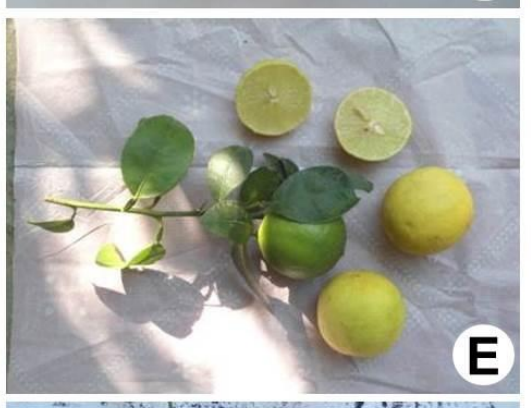

E
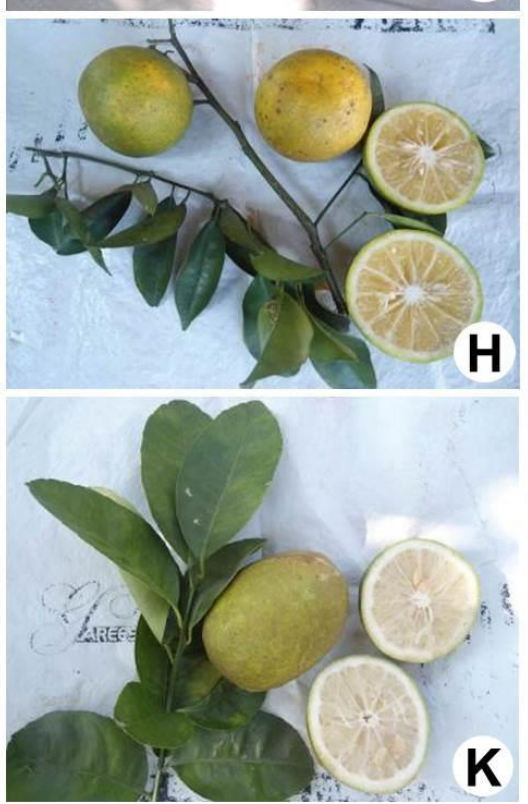
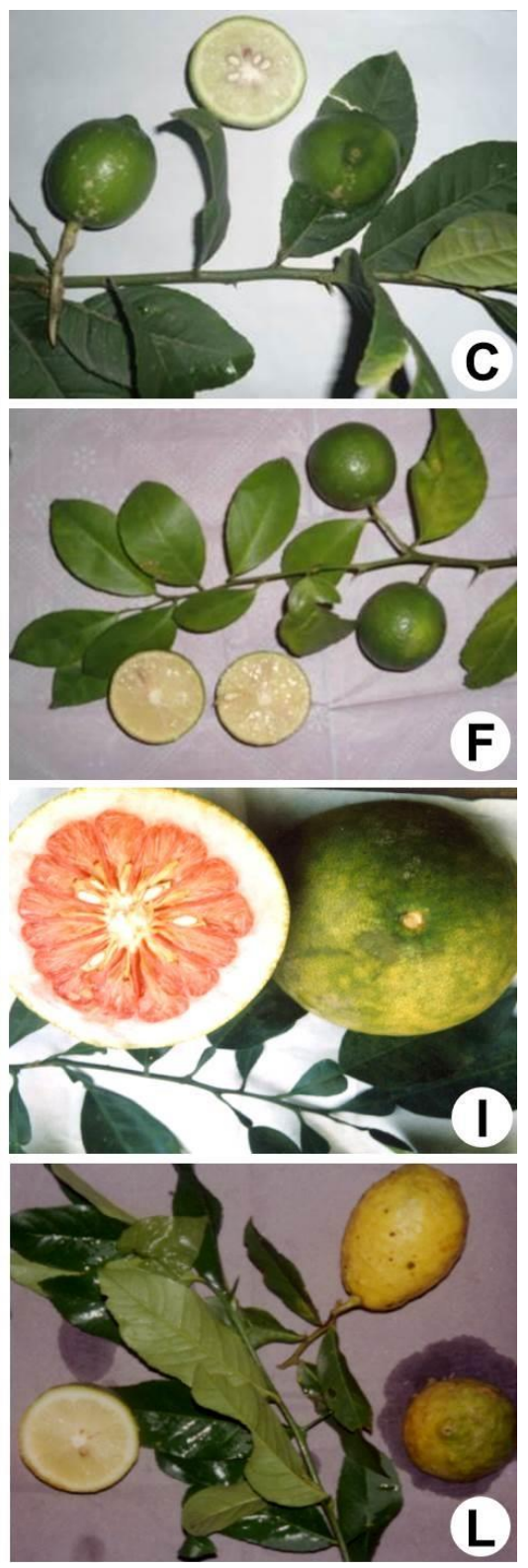

Figure 2. Photograph showing different Citrus species found in Kokrajhar district: A, Citrus limon Burm f. var. Assam lebu/China lebu (Assam lemon); B, Citrus limon Burm f. var. Elachi lebu (Cardamom lemon); C, Citrus limon Burm f. var. Pati lebu/Jora nemu; D, Citrus aurantifolia (Christm.) Swin. var. Oval fruited; E, Citrus aurantifolia (Christm.) Swin. var. Round-fruited; F, Citrus jambhiri Lush.; G, Citrus reticulata Blanco (Santara/ Sumthira/ Kamala); H, Citrus nobilis Lour (Mitha tulia/ Jamir tenga/ Jeneru tenga); I, Citrus grandis L. Osbeek var. Jambura /Robab tenga; J, Citrus sinensis L. Osbeek (Mithamuri); K, Hybrid variety (Mithamuri); L, Citrus medica Linn. var. Nare/Narang/Jora tenga 
The survey on the distribution pattern of both wild and domesticated Citrus species in the different locality of the district (Fig. 1) showed that their distribution is more or less similar both in rural and semi-urban areas. A variety of Citrus species were found to be distributed in different places of Kokrajhar district in wild, semi-wild and cultivated forms. In addition, a distinct morphological variation of the species with healthy growth of semiwild and wild forms is observed which indicates their adaptability to the local agro-climatic conditions. Among them, citron (C. medica) an indigenous species of Assam (Bhattacharya \& Dutta 1951) was found in tropical forests of the district. Roxburgh (1832) encountered citron in Garo hills of Assam, and Hooker (1875) and further revised by BSI, Dehradun in (1990) and reported it in Sikkim, Garo hills, Khasi hills and also in the Western Ghats and Satpura range. Another species lemon (C. limon) has shown diverse forms of varieties as well as healthy growth habits in different localities. The rough lemon (C. jambhiri) was also found widely distributed in the region which was earlier reported as indigenous species to north eastern Himalayan Zone (Bhattacharya \& Dutta 1951). The king orange (C. nobilis) was found to grow in semi-domesticated form. Similarly, both mandarin orange $(C$. reticulata) and sweet orange $(C$. sinensis) are two other popular Citrus species that grow in the district and generally cultivated in orchards commercially. Moreover, sweet pummelo (C. grandis) is also commonly cultivated in orchards and grow in the backyard.

Citrus is considered to be one of the most important fruit crops since prehistoric time because of its consumer demand and wide uses in different kinds of processed product (Singh 1999, Ghosh 1999). It is the most widely studied genus (Webber 1943, Swingle 1943, Aiyappa \& Srivastava 1965, Hodgson 1967, Tanaka 1977, Bhattacharya \& Dutta 1951 \& 1956, Singh 2001) on different aspects of classification and cultivar development. The morphological character of fruit is considered as a basic tool for identification as well as classification and the important characters can be derived from the observation of both live and herbarium specimens. During the study, a large array of variation of the fruits has been observed among the eight species which has genetic as well as taxonomic potential. The species bear special kind of fruit i.e. hesperidium of variable shape and size such as spherical, globose, ovate, ovate-oblong etc. Close similarities have been observed in between $C$. reticulata Blanco and $C$. nobilis Tan. in regard to globose shaped fruit and thin rind (Fig. 2). However, the size of the fruit of $C$. reticulata Blanco (size $4.5-5.9 \mathrm{~cm}$. ht., $6.0-6.8 \mathrm{~cm}$. diam.) is larger than C. nobilis Tan. (size 3.0-6.4 cm. ht., 3.2-6.5 cm. diam.). The species, C. grandis (L.) Osbeck has large fruit with spherical shape (size 13.0-19.5 cm. ht., 14.0-18.5 cm. diam.) and with a thick and spongy rind as well as mesocarp while $C$. sinensis Osbeck. has a medium-large fruit (size 6.0-8.5 cm. ht., and 4.5-6.0 cm. diam.) of spherical-oblong shape are distinct from other species. However, it has been observed that C. aurantifolia (Christm.) Swin. is medium large (size 4.3-5.1 cm. ht., 4.2-5.1 cm. diam.), round shaped fruit, (7.3-9.1 cm. ht., $4.2-5.1 \mathrm{~cm}$. diam.) oval shaped fruit with light yellow colour and the mamillate apex. C. limon Burm f. can be easily identified on the basis of the oval shaped fruit (size 10-14 cm. ht., 5-8 cm. diam.) with necked base, mamillate apex and lemon yellow colour. Similarly, $C$. medica L. has oblong shaped fruit, large to mediumlarge (size 9-11 cm. ht., 6.0-7.3 cm. diam. to 5.2-6.0 cm. long, 3.5-4.4 cm. diam.), large mamillate apex and yellow colour. In addition, oval shaped fruited C. sinensis $(6.0-8.5 \mathrm{~cm}$. ht., $4.5-6.0 \mathrm{~cm}$. diam.) can be separated from C. jambhiri $(6.0-7.5 \mathrm{~cm}$. ht., $6.5-7.5 \mathrm{~cm}$. diam.) easily.

While conducting an experiment on the propagation of selected Citrus varieties, it has been observed that the rate of seed germination in all hormone treatment irrespective of concentration was found to be superior over distilled water treatment. The treatment $\mathrm{GA}_{3}-800 \mathrm{ppm}$ (gibberellic acid) resulted in the highest rate of germination (90\%). The lowest germination percentage was recorded (40\%) in control plot. On the other hand cutting of $C$. limon Brum f. and $C$. medica L. has easily sprouted within 15 days after planting, but $C$. aurantifolia Swin. grew slowly. After three months of observation, it was found that the success rate in case of two species i.e. C. limon and C. aurantifolia was $80 \%$ and $30 \%$ respectively. Moreover, data recorded on air layering practice (Fig. 3) from the field has revealed that it the mostly used technique to propagate $C$. aurantifolia Swin and C. limon Brum $\mathrm{f}$. with the highest percentage of survival rate up to $90 \%$ with maximum production.

According to horticulturist vegetative propagation methods is the greatest single step which can be taken up for the improvement of tropical fruit culture. The methods commonly used in the tropics are cutting, layering, budding, inarching, marcottage and tissue culture. The new technique of mist propagation for improving the rooting of cuttings has been very widely applied in NE regions although the use of special rooting composts is gaining importance (Mukherjee \& Majumder 1983). Another method, air-layers of varieties to be multiplied and rooted shoots are separated and can be planted directly in the field or in the nursery. 

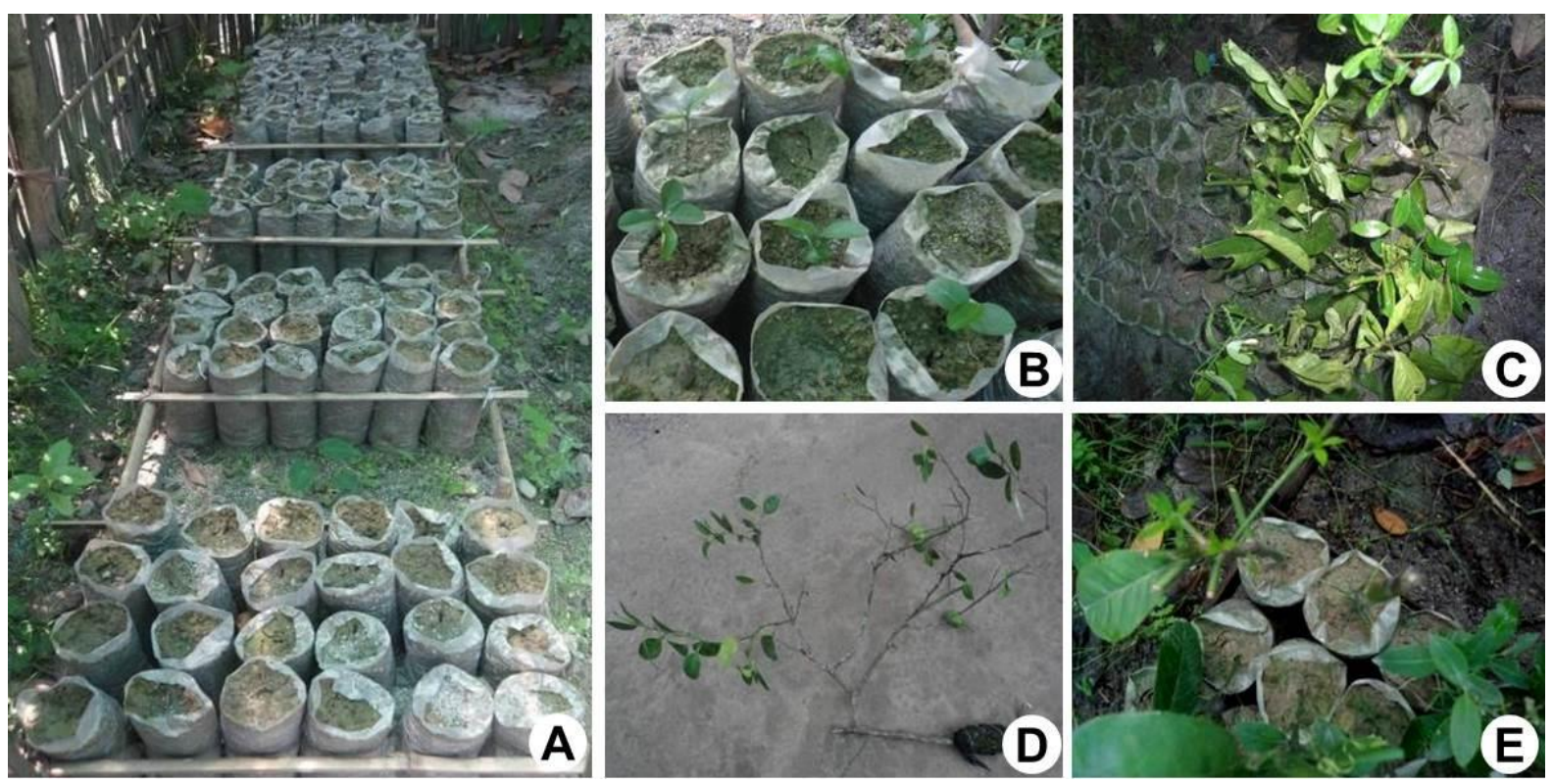

Figure 3. Photograph showing nursery preparation and different propagation techniques: A, Nursery beds prepared for planting of Citrus spp.; B, Two months old Citrus reticulata seedling; C, Planted multiple node cutting; D, Sapling prepared through air layering; E, Sprouted sapling of C. limon, C. medica and C. aurantifolia in the nursery.

\section{CONCLUSION}

Citrus species and varieties grow naturally in different localities all around the Kokrajhar district. The studied species possess distinct morphological characters which have determined their systematic position as separate species and the large array of variation of citrus fruits shows its genetic potential. Rare varieties like $C$. nobilis (Jeneru tenga) and $C$. limon (Elachi lebu) are required to be conserved immediately by adopting adequate strategies. Regarding its propagation, it can be hypothesized that Citrus is a seed propagated plant and vegetative propagation can be done by means of cutting, layering, and tissue culture. Pre-sowing seed treatment with hormone can improve the rate of germination and growth of the seedling. Air layering is the most common method used to propagate $C$. aurantifolia Swin and C. limon Brum f. by orchardists of Kokrajhar district. Citrus production in Kokrajhar district is not encouraging even though suitable agro-climatic conditions prevail for large scale cultivation. Therefore, it is required to cultivate with the right variety of seedling that can be developed by using proper nursery technique.

\section{ACKNOWLEDGEMENTS}

Authors are thankful to UGC-NERO, Guwahati for financial support in the form of Minor Research Project sanctioned in 2013 and DBT sponsored Biotech Hub, Science College, Kokrajhar for providing lab facility. Thanks are due to the Principal, Science College, Kokrajhar for his constant support. The help received from forest guard, laboratory assistant and orchardist of Kokrajhar district are also highly acknowledged.

\section{REFERENCES}

Aiyappa KM \& Srivastava KC (1980) Oranges, lemons and limes. Bulletin, Directorate of Extension, Ministry of Agriculture \& Irrigation, Shastry Bhawn, New Delhi.

Bhattacharya SC \& Dutta S (1951) Citrus varieties in Assam. Indian Journal of Genetic \& Plant Breeding 2(1): $57-62$.

Bhattacharya SC \& Dutta S (1956) Classification of Citrus fruits of Assam, In: Scientific Monograph No. 20. ICAR, New Delhi.

Chaudhury BK \& Chakrawar VR (1980) Effect of some chemicals on the germination of Kagzi lime seeds. Maharashtra Agricultural University Journal 5(2): 173-174.

Director of Agriculture \& Horticulture, Kokrajhar, BTAD, Assam. Annual Report 2011-2012.

Dutta AC (1964) Botany for Degree Students, $6^{\text {th }}$ edition. Oxford University Press, pp. 309-316.

Ghosh SP (1999) Citrus Industry in Asia. In: Singh S \& Ghosh SP (eds) Hi-Tech Citrus Management. pp. 1-22.

Gogoi M \& Bhansali R (2015) Need to Protect BTAD Forest Coverage from Anthropogenic Pressure. SouvenirPlatinum Jubilee Celebration Issue, Basugaon Secondary School, Kokrajhar. pp. 160-163. 
Gogoi M (2014) Study on Germination and Growth of Citrus spp. of Kokrajhar district, BTAD. Assam. Project report submitted to UGC-NERO, Guwahati.

Gogoi M, Singh B, Rethy P, Mishra AK \& Kalita S (2003) Citrus species in Arunachal Pradesh: Diversity and Economic Prospect. Indian Journal of Citriculture 2(1): 1-9.

Hodgson RW (1967) Horticultural varieties of Citrus. In: Reuther W, Webber HJ \& Batchelor LD (eds) Citrus Industry. Vol. I. University of California, USA, pp. 431-591.

Hooker JD (1875) The Flora of British India. Vol. I. Reeve and Co. London, pp. 484-517.

Jain SK \& Rao RR (1977) Field and Herbarium Methods. Today \& Tomorrow Printers and Publisher, New Delhi.

Kalita S, Singh B, Rethy P \& Gogoi M (2002) Effect of Plant Hormones on Seed germination of Citrus reticulata Blanco. Journal of Hill Research 15(2): 108-112.

Lawrence GHM (1951) Taxonomy of vascular plant. Oxford and IBH Publishing Co. Pvt. Ltd., New Delhi.

Mukharjee SK \& Majumder PK (1983) Vegetative Propagation of Tropical and Subtropical Fruit Crops, Revised edition. ICAR, Bulletin No. 45.

Rajput CBS \& Haribabu RS (1985) Citriculture. Kaylani publishers, New Delhi.

Randhawa GS \& Srivastava KC (1986) Citriculture in India. Hindustan Publishing Corporation, New Delhi.

Roxburgh W (1832) Flora Indica. Vol. III. New York Botanical Garden.

Singh B, Rethy P, Gogoi M \& Kalita S (2004) Managing Tea nursery for more returns. Indian Horticulture Journal July-Sep: 4-5.

Singh B, Rethy P, Kalita S \& Gogoi M (2001) Food security through horticultural crops in Arunachal Pradesh. Business Perspective 3(2): 143-166.

Singh B (1981) Establishment of First Gene Sanctuary in India for Citrus in Garo hills. Concept Pub. Co., New Delhi.

Singh G (2012) Protocols and Standards for Vegetative Propagation of Fruit Crops. Dept. of Agriculture \& Cooperation, Govt. of India.

Singh HP (2001) Citrus. In: Bose TK, Mitra SK \& Sanyl D (eds) Fruits: Tropical and Sub-tropical, $3^{\text {rd }}$ edition. Vol. I. Naya Udyug, Calcutta, pp. 101-118.

Singh S (1999) Citrus in India. In: Singh S \& Ghosh SP (eds) Hi -Tech Citrus management. ISC / ICAR / NRCC, pp. 278-303.

Swingle WT (1943) The Botany of Citrus and its wild relatives of the orange Sub- Family. In: Webber HJ \& Batchelor LD (eds) Citrus Industry, $1^{\text {st }}$ edition. Vol. I. University of California, USA, pp. 129-474.

Tanaka T (1977) Fundamental discussion of citrus classification. Studia Citrologica 14: 1-6.

Webber HJ (1943) Cultivated varieties of Citrus. In: Webber HJ \& Batchelor LD (eds) The Citrus Industry, $1^{s t}$ edition. Vol. I. University of California, USA, pp. 475-642.

Williamson JG \& Jackson LK (1994) Citrus Propagation. Fact Sheet HS-86, University of Florida. 